\title{
Toward a definition of paratexts and paratextuality: The case of ancient Greek manuscripts
}

Since the beginning of my involvement in the ParaTexBib project-or "Paratexts of the Bible: Analysis and Edition of the Greek Textual Transmission"-launched by Martin Wallraff in 2012 and now funded by an ERC Advanced grant, ${ }^{1}$ the notion of "paratexts" and "paratextuality" has occupied my thoughts, as the project raises many practical and theoretical challenges. It boils down to a simple question: what exactly, speaking theoretically and concretely, is a paratext in an ancient codex?

In the current specialised literature, there is a striking lack of shared terminology and methodology for dealing with paratexts, marginal notes and other types of secondary content in ancient codices in general and for the way they relate to one another and to the main contents in the same book.

This paper aims to make a contribution towards filling this gap. The first part surveys the history of the paratext as a concept within Gerard Genette's theoretical framework and its use in the current scholarly literature in reference to ancient manuscripts. It also addresses a number of theoretical questions: it calls for a clarification of the various current and sometimes contradictory meanings of the words "text" when designating the "contents" in manuscript research; it discusses the paratextual function of some codicological features and argues that they should not be called paratexts; and it explores the use of the term "book production" as a corresponding concept to "publishing” for printed books.

The second part focuses on the various types of secondary contents in Greek New Testament manuscripts and suggests a way to organise them into two main classes

1 See Wallraff/Andrist 2015, Andrist/Wallraff 2016 and www. paratexbib.eu (accessed 16 November 2017).

Note: Many thanks to the organisers for their kind invitation and their excellent organisation of the conference; to Marilena Maniaci, Liv Ingeborg Lied, Martin Wallraff and Emanuele Castelli for stimulating discussions and input; to Michael Friedrich, Alessandro Bausi and Marie-Odile Boulnois for their invitation to present this topic in Hamburg and Paris, and for the fruitful exchanges held with them and the participants of these presentations; also to Drew Longacre and Ulrich Schmid for some very useful bibliographical references, and to Saskia Dirkse and Roderick Saxey for proofreading the text and contributing many questions and remarks. of "book producers' paratexts" and "post-production paratexts." Even though paratextuality is a phenomenon which occurs in all ancient manuscript traditions, biblical manuscripts (especially those belonging to the Greek cultural sphere) form a promising case study for two reasons in particular. ${ }^{2}$ First, the primary content-the biblical books-is clearly identified and distinct from the secondary content. Second, the wealth of preserved manuscript witnesses allows one to make a clear distinction between various types of secondary content, helping us recognise which paratexts are traditional and which are unusual or even exceptional. The usefulness of these categories in describing and understanding paratextuality in other Greek and non-Greek manuscripts, both biblical and non-biblical, remains to be studied in broader and more collaborative contexts. It is my hope, however, that the concepts here proposed will form the basis of further discussions and perhaps also inspire further research.

\section{Theoretical considerations}

\subsection{The limits of Gérard Genette's concept of paratext when applied to manuscript studies}

The concepts of "paratext" and "paratextuality" were developed by the French literary critic Gerrard Genette in three books published in 1979, 1982 and 1987, all of which were translated into English. ${ }^{3}$ In Genette's view, paratexts represent one relational category in a larger theoretical framework built around the concept of what he called "transtextuality," which he himself roughly defined in 1982 as "all that sets the texts in a relationship, whether obvious or concealed, with other texts." ${ }^{4}$

When it first appeared in Genette's system in 1979, the term "paratextuality" was used specifically to describe

2 On the peculiarities of medieval Latin Bibles, see Maniaci/ Muzerelle/Ornato 1999, 291-93.

3 Genette 1992; 1997a; 1997b.

4 Genette 1997a, 1; Genette 1982, 7: "grossièrement ... tout ce qui met un texte en relation, manifeste ou secrète, avec un autre texte.” 
the kind of relation existing between two texts when an author imitates or transforms an already existing work in a humorous or serious manner, as in a parody or in a pastiche. ${ }^{5}$

In 1982, Genette made an important revision to the meaning of the term, ${ }^{6}$ which was employed to describe, since then, "the relation between a literary work and all the texts that surround, accompany or even extend it." He compares these texts to "thresholds" or "vestibules." In order to avoid confusion in terminology, it is important to note that the parodic/pastiche relation was at this time subsumed into the concept of "hypertextuality."

According to Genette, paratexts are either "epitexts" (outside the book), like flyers, letters, interviews, etc., or they are "peritexts" (inside the book), including titles, subtitles, footnotes, prefaces, etc. He condenses this dichotomy into the following formula: "paratext = peritext + epitext." As Richard Macksey effectively summarises it in his foreword to the English edition, paratextuality

5 Genette 1979, 87 (speaking of transtextuality): “ j’y mets encore d'autres sortes de relations-pour l'essentiel, je pense, d'imitation et de transformation, dont le pastiche et la parodie peuvent donner une idée, ou plutôt deux idées, fort différentes quoique trop souvent confondues, ou inexactement distinguées-que je baptiserai faute de mieux paratextualité (mais c'est aussi pour moi la transtextualité par excellence), et dont nous nous occuperons peut-être un jour, si le hasard fait que la Providence y consente”; in English, Genette 1992, 82: "under transtextuality I put still other kinds of relationshipschiefly, I think, relationships of imitation and transformation, which pastiche and parody can give us an idea of, or rather two ideas, for they're very different, although too often confused with each other or incorrectly differentiated. For lack of a better term, I'll christen them paratextuality (which to my mind is transtextuality par excellence), and perhaps someday, God willing, I'll look into it."

6 See Genette 1982, 7, 13; in English, Genette 1997a, 1, 5.

7 Genette 1982, 10: paratextuality is defined as the relation, "que le texte proprement dit entretient avec ce que l'on ne peut guère nommer que son paratexte: titre, sous-titre, intertitres ; préfaces, post-faces, avertissement, avant-propos, etc.; notes marginales, infrapaginales, terminales ; épigraphes ; illustrations ; prières d'insérer, bande, jaquette, et bien d'autres types de signaux accessoires, autographes ou allographes, qui procurent au texte un entourage (variable).” In English, Genette 1997a, 3: “the relationship that binds the text properly speaking ... to what can be called its paratext: a title, a subtitle, intertitles; prefaces, postfaces, notices, forewords, etc.; marginal, infrapaginal, terminal notes; epigraphs; illustrations: blurbs, book covers, dust jackets, and many other kinds of secondary signals, whether allographic or autographic."

8 "Hypertextuality" more largely defines the transtextual relation of imitation or transformation, including all kind of thematic or stylistic amplifications. See Genette 1997a, 5: "By hypertextuality I mean any relationship uniting a text B (which I shall call the hypertext) to an earlier text A (I shall, of course, call it the hypotext), upon which it is grafted in a manner that is not that of commentary."

9 Genette 1997b, 5. is a concept "comprising those liminal devices and conventions, both within the book (peritext) and outside it (epitext), that mediate the book to the reader."10

Despite its clarity and attractiveness, Genette's theory cannot be directly transposed onto the world of ancient manuscripts, because his primary focus was on literary works in print (mostly novels). His understanding of paratexts is strongly tied to texts published by their authors or under their authors' control. As he said explicitly,

by definition, something is not a paratext unless the author or
one of his associates accepts responsibility for it, although the
degree of responsibility may vary. ... The official [type of para-
texts] is any paratextual message openly accepted by the author
or publishers or both-a message for which the author or pub-
lisher cannot evade responsibility. ... The unofficial (or semioffi-
cial) is most of the [time] authorial epitext: interviews, conversa-
tions, and confidences, responsibility for which the author can
always more or less disclaim with denials of the type "That's not
exactly what I said."11

Thus, for Genette the text is the literary work which an author has created and made public; it is the core of his publication project. Everything added or produced for the sake of its publication can be called a paratext. Paratexts (or at least peritexts) are also part of the editorial project but they do not belong to its core. As we also find in the passage cited above, Genette further divides paratexts into two categories. First, the author's paratexts, including his preface, titles, subtitles, etc., and second, the publisher's paratexts, including the cover, all the writing on the cover pages of the book, the title page, etc. Genette even mentions the format, the typesetting and the paper as types of publisher's paratext. ${ }^{12}$ Later on, he also adds the illustrations found in books. ${ }^{13}$

On a theoretical level, everything that is added to the book at a later point is not on Genette's radar and cannot be considered a paratext; it is rather in the realm of "metatexts." In Genette's world the author and the publisher work together to produce the same book-a very rare occurrence in ancient and medieval manuscripts. ${ }^{14}$ As a result, in our understanding of Genette's perspective, most of the supplementary materials in the biblical manuscripts (especially marginal readers' notes) are not

10 Genette 1997b, xviii.

11 Genette 1997b, 9-10.

12 Genette 1997b, 17-36.

13 Genette 1997b, 406.

14 There are well-known cases where medieval authors, like Boccaccio, participated to the definition of the editorial typology of their works. One can also recall antique and medieval authors who gave instructions on how their works should be copied, like Evagrius Ponticus or Hrabanus Maurus. 
paratexts, since they were added after the biblical authors and their first (if any) "publishers" relinquished control over their texts.

On a practical level, however, it should be recognised that Genette was aware of this problem. Although he was able to open some important doors, in the case of paratexts in medieval manuscripts, he never really explored beyond them. For example, in his sub-chapter on "allographic prefaces," he discusses the prefaces in printed editions of classical authors like Ovid or Homer. ${ }^{15} \mathrm{He}$ mentions that these prefaces are necessarily posthumous and, as such, completely beyond the author's control. He nevertheless still considers them paratexts-even though, he adds, the "allographic preface clearly draws it toward the border that separates (or rather, toward the absence of a border that does not sharply separate) paratext from metatext."16 Further, in his chapter on the "publisher's peritext" he even goes so far as to declare,

this is not to say that the (much longer) pre-Gutenberg period, with its handwritten copies that were really even then a form of publication, knew nothing of our peritextual elements; and below we will have reason to ask how Antiquity and the Middle Ages handled such elements as the title or the name of the author, whose chief location today is the publisher's peritext. ${ }^{17}$

Genette implicitly recognised the limits of his theory when applied to ancient manuscripts. Unfortunately, he did not strive to adjust or develop it in order to embrace them as well.

\subsection{The concept of paratext in manuscript studies}

Despite the fact that Genette's theory is not well adapted to manuscript studies, his ideas have nonetheless proven to be very fruitful for scholars working with ancient manuscripts, especially in recent years. In the past, the concept of the paratext has frequently been used in scholarly discourse in a variety of ways but only recently the discussion of its theoretical dimensions has started seeing marked developments.

15 Genette 1987, 265-78 = 1997, 263-75. Interestingly, he does not mention the editions of the Bible, and the word Bible does not appear in his index.

16 Genette 1997b, $270=$ 1987, 273.

17 Genette 1997b, 16 = 1989, 21. Genette also had a prejudiced concept of medieval manuscripts, for example when he writes “... in antiquity and the Middle Ages, periods in which texts frequently circulated in their almost raw state, lacking any formula of presentation" (Genette 1991, 263).
As early as 1997, in the proceedings of a conference dedicated to the titles of texts in manuscripts, the word "paratext" appears several times in relation to them. ${ }^{18}$ Throughout the conference papers, when it does not refer to the titles, it is at least understood as designating a textual element which accompanies the main text of a manuscript.

In the preface of a multi-author volume entitled Paratext and Megatext as Channels of Jewish and Christian Traditions, August Hollander, Ulrich Schmid and Willem Smelik recognise the limits of Genette's author-focused definition. In practice, they include in their concept of paratext and "megatext" a wide range of written elements, from punctuation to translations, including of course accompanying elements such as prefaces, headings and illustrations. ${ }^{19}$

In the first decade of twenty first century, research on paratextuality in printed books was an important topic in Italy, particularly in the journal "Paratesto" and in the scholarly initiatives of Marco Santoro, Maria Gioia Tavoni and Maria Antonietta Terzoli, among others. In this context, several Italian scholars have also worked on paratextuality in ancient manuscripts. For example, Mariangela Regoliosi gives a grand tour of the paratextual elements in ancient manuscripts, which she understands primarily as the written elements around the main text, such as the frontispieces, the dedicatory pieces, the titles, the marginal "notabilia" of the scribe, and the index. ${ }^{20}$ She also includes the marginal notes of the readers. Similarly, Giorgio Montecchi has compared various aspects of the layout in manuscripts and early printed books and discussed in some places the "paratextual value" of these physical features. ${ }^{21}$

Eric Scherbenske, first in a 2010 article and again, in greater detail, in his 2013 monograph Canonizing Paul: Ancient Editorial Practice and the Corpus Paulinum, explores the "making of an edition" in ancient biblical manuscripts. He uses the term "paratext" to indicate the

18 Fredouille et al. (eds.) 1997; see the use of the word by Michelle Fruyt, p. 31; Simone Déléani, pp. 399, 421, 425; Pierre Petitmengin, pp. 491, 501. Peter Lebrecht Schmidt prefers the expression "paratextual elements," like in his title "Paratextuelle Elemente in lateinischer Fachprosa," in which he includes items like "Titel und Gedichtüberschriften, Inhaltsangaben oder Kennzeichung von Dialogpartnern" (p. 223). The concept is also used several times in the conclusion by Philippe Hoffmann, "Titrologie et paratextualité," who, among other things, pleads for "une ecdotique des titres et de tous les éléments paratextuels" (p. 584).

19 Hollander/Schmid/Smelik (eds.) 2003, particularly vii-viii, xii. 20 Regoliosi 2006, 21.

21 Montecchi 2005. 
verbal elements that frame the biblical text in a codex. Concentrating on the corpus of Pauline epistles and influenced by Euthalian categories, he groups them in "A. Bioi," "B. Hypotheses," "C. Kephalaia” and "D. Other aids."22 He then speaks of "paratextual material" or "paratextual voices," which "transformed early Christian manuscripts from mere receptacles of the text into vehicles for transmitting its interpretation." ${ }^{23}$

In his 2012 study, Michael Curschmann also makes use of the of the word "paratext" to designate first-hand textual elements in the pictures of a specific manuscript in the Abbey of Admont. ${ }^{24}$ But if these small pieces of text are part of the initial composition, one wonders whether they should really be considered paratexts. Moreover, the author never refers to any "Genettian" category, and endows the word "paratext" with a different meaning, creating confusion in the scholarly vocabulary.

Another group of scholars, working with Qumran manuscripts and ancient Jewish literature, also started using the word "paratext," though consciously, in a sense which is more in line with the definition outlined by Genette in $1979 .^{25}$ Their approach to Genettian paratexts is set forth in the introduction to the proceedings of a conference held in Vienna in 2007, published in 2010 with the title In the Second Degree: Paratextual Literature in Ancient Near Eastern and Ancient Mediterranean Culture and Its Reflections in Medieval Literature. Armin Lange writes in the introduction that "the participants of the Vienna conference and the authors for this volume are evenly split as to which term to use for the scholarly description of literature in the second degree." 26 The position of those who support a "revivalist" meaning must be understood in their effort to use neutral language when dealing with modifications, amplifications and rewritings ${ }^{27}$ of texts which were not yet part of the Hebrew canon of the Bible.

This approach presents major problems, given that according to the established Genettian system, the

22 Scherbenske 2013, 55-70.

23 Scherbenske 2010, 139.

24 Cushmann 2012.

25 See above pp. 130-1. See examples of this revival use of this meaning in Lange 2008, 207 n. 38, and Alexander/Lange/Pillinger 2010 (interestingly, the title of this last work In the Second Degree: Paratextual Literature in Ancient Near Eastern and Ancient Mediterranean Culture and Its Reflections in Medieval Literature is a hypertextual reworking of the title of Genette's book which precisely changed the meaning of the word paratext, Palimpsestes. La littérature au second degré)!

26 Lange 2010, 19, see also 16-20. In the same volume, see also Jacques T. A. G. M. van Ruiten, 66-67.

27 Apparently assimilated here to the "pastiches" of Genette's terminology. transtextual relation they describe fall within the realm of hypertextuality, as the title of the proceedings shows. ${ }^{28}$ Moreover, the "revivalists" do not suggest another expression to describe Genette's broadly accepted use of "paratexts." The result of this is, as Anders Klostergaard Petersen correctly remarks, that "a return to the older terminology of Genette may cause more confusion than contributing to create conceptual clarity," ${ }^{29}$ especially since other scholars active in the same domain, like Emanuel Tov or George Brooke, were already using the term in closer alignment with Genette's standard and widely-accepted definition..$^{30}$ It is interesting that very few of the studies mentioned above have used the word "peritext" to describe the accompanying texts or features in a manuscript, though such would be more in agreement with Genette's terminology. ${ }^{31}$ Nor did they generally include the physical features of the manuscripts ${ }^{32}$ in their definitions of paratexts.

As noted before, the word "paratext" and the concept of paratextuality has become ever more popular in manuscript studies in recent years, but not always with the benefit of a solid theoretical framework. In addition to the works of Scherbenske and Petersen just cited, several publications can be mentioned.

It is not surprising that various articles in the multi-author volume On the Fringe of Commentary: Metatextuality in Ancient Near Eastern and Ancient Mediterranean Cultures, which appeared in $2014,{ }^{33}$ also deal with paratextuality given that there is a somewhat porous border

28 See also George Brooke in the same volume, 43-45.

29 Petersen 2014, 25 n. 28. See also Brooke 2010, 44: “The term 'paratext,' preferred by some scholars ... is not really adequate for the task of categorizing literary activity that involves imitation and dependence of one sort or another." Speaking of Lange's new terminology, he adds, "It is equally problematic to move to the term 'paratextual' since that term has been coined by others for other purposes" and he goes on quoting Genette's standard definition of paratextuality.

30 For example, Tov defines paratexts fairly broadly as "elements indicated by scribes in manuscripts beyond the consonants, vowels, and accents" (Tov 2004, 202). He includes in paratexts some scribal practices, like "extraordinary points" and "unusually shaped letters." See for example Tov 2004, 201-5: Appendix 10 "Paratextual elements in medieval Masoretic manuscripts," based on Tov 1999 "Paratextual elements in the Masoretic manuscripts of the Bible compared with the Qumran evidence."

31 The word was not often used in the studies on printed books either; see as an exception Castiglioni 2005. See also the remarks of Rozzo 2006, 213.

32 See above p. 131 and n. 12. For an exception, see Montecchi 2005, mentioned above.

33 Aufrère/Alexander/Pleše (eds.) 2014. These are the proceeding of a conference in Aix/Marseille organised within the network "The 
between the two concepts as well as some overlap, as Sydney Aufrère notes in the introduction..$^{34}$ In this volume, George Brooke deals with the physical features of a codex from Qumran. He clearly states, "starting with Genette I take all the non-verbal and verbal scribal phenomena used to present the text as paratextual", ${ }^{35}$ including aspects such as the shape and size of the scrolls, the layout including the ruling and the size of the columns, text divisions etc. However, even if "most of what will be presented falls under the broad umbrella of paratextuality as peritext,"36 Brooke opts for periphrases like "non-verbal paratextual phenomena," "paratextual items," "paratextual indicators," or "paratextual data," and does not directly call the physical features "paratexts" or "peritexts."

The collective book entitled The Roman Paratext: Frame, Texts, Readers (also published in 2014) ${ }^{37}$ begins with some central questions, "What is a paratext, and where can we find it in a Roman text? What kind of space does a paratext occupy, and how does this space relate to the text and its contexts?" 38 In order to answer these (and other) questions, the authors mainly explore what Genette would call "authorial paratexts," and study what kind of paratexts the authors built in their works; how they relate to the "text" and contribute to constructing an audience, etc., generally not in relation to the handwritten tradition or to specific manuscripts. ${ }^{39}$ Several articles in this interesting

Hermeneutics of Judaism, Christianity, and Islam" and following the above-mentioned conference in Vienna.

34 Aufrère 2014, 8; see also the remarks of Daniel Stöckl ben Ezra (who explores the concepts of oral and ritual paratextuality), $197 \mathrm{n}$. 8, 206-7.

35 Brooke 2014, 176. See also n. 6, where he rejects Gilles Dorival's suggested expressions "protext" or "antetext" for designating preparatory physical features like ruling. Interestingly, Dorival's suggestion re-establishes the difference between the written and preparatory aspects of the codex (see below).

36 Brooke 2014, 176. See also 178 n. 18: "In some ways I am extending the definition of peritextual to include everything on the manuscript that surrounds the text; I do not use the term just to refer to supplementary textual items that adorn the text."

37 Jansen (ed.) 2014.

38 Jansen (ed.) 2014, i.

39 There are several exceptions, particularly chap. 2 by Roy Gibson (in Jansen [ed.] 2014), mainly about the lack of the maybe original prefatory index in the manuscripts of the Letters of the Younger Pliny (except one); chap. 8 by Donncha O'Rourke, including remarks about the position of paratexts in ancient papyrus books; chap. 4 by Shane Butler, about capitulation in Cicero's manuscripts-this article, which was published at an earlier point and was not written from the perspective of paratextual studies, is republished in the volume, "with corrections," as a supplementary case study; chap. 11 by Irene Peirano, about the paratextuality of the sphragis; some remarks by Laura Jansen in chap. 13 on the equivalent of book covers in ancient scrolls and on Ovid as editor. series of study cases tackle the question how the evolving "mises en livre" (our expression), including the loss of an ancient preface and/or the surge of editorial traditions (organising the texts, adding sub-titles etc.), modified the interaction between the texts and the readers. Stimulating theoretical questions are frequently raised, mostly about the limits and applicability of the Genettian concept of paratext, ${ }^{40}$ and the authors attempt to answer these questions using a broad conception of paratexts, including, when significant, elements of the layout, book divisions, internal structure of the works and physical format. ${ }^{41}$

Published in 2016, Tracing Manuscripts in Time and Space through Paratexts explores quite a different kind of paratextuality. ${ }^{42}$ The book deals primarily with colophons but also includes glosses, possessor marks, even quire marks, etc. In a pioneering cross-cultural approach, this interesting series of eight essays reveals the similarities and differences of manuscripts from diverse cultural backgrounds and illustrates both the challenges and advantages of using paratexts in reconstructing the history of the manuscripts. Moreover, this volume (the first result of an on-going project about paratexts by the Centre for the Study of Manuscript Cultures at the University of Hamburg), which discusses a large variety of paratextual situations in different cultural contexts, raises several thought-provoking ideas about the theoretical dimensions of paratexts..$^{43}$ For example, paratexts are divided "into two sub-categories: the first one provides explicit temporal and spatial information; this is the case for colophons, prefaces, postfaces, etc., in which the date and place of production are usually recorded. The second sub-category, on the other hand, contains non-explicit information that

40 See for example Laura Jensen, 1-16; Ducan F. Kennedy, 19-22, 24; Matthijs Wibier, 57-58, 68-69; Donncha O’Rourke, 156-57; Laura Jansen, 262-66. Outside the world of manuscripts strictly speaking, one also notices chap. 7 by Alison E. Cooley, which extend the concept of paratextuality to Latin epigraphy; chap. 9 by Hérica Valladares, who explores the unframed floating figures on Roman wall paintings as "paratexts" to the architectural ensemble they are part of; chap. 10 by Ellen Oliensis, who makes a distinction "between paratextuality and metapoetics" (see 207-8, 212-14), and offers an "anti-paratextual reading" of some verses of Ovid.

41 For example, Shane Butler, chap. 4 (cf. supra); Matthijs Wibier, chap. 3, about the "topography" of Roman law books; Bruce Gipson, chap. 12, cf. p. 246, etc.

42 Ciotti/Lin 2016.

43 The reader learns that the project explored the functions of paratexts, whose three main functions are presented as "(1) structuring (e.g. offering navigation aids that guide the reader, such as tables of contents), (2) commenting (e.g. glosses and annotations that offer interpretations and explanations of a text), and (3) documenting”, Ciotti/Lin (eds.) 2013, Introduction, 7. 
can only be accessed by means of philological, palaeographical, codicological and material-based investigation; glosses may be written in a language or register which is peculiar to a specific region and moment in time, for example." ${ }^{44}$ It seems, however, that the intended scope of this statement is limited to paratexts with a documentary function ${ }^{45}$ and does not apply to all of them, since paratexts like traditional titles, prefaces or tables of contents (which most of the time are written by the main scribe) often do not provide any clues about the history of the codex. ${ }^{46}$

The studies mentioned above bear witness to both the fruitfulness of the concept coined by Genette and the need for greater awareness and precision about its use in manuscript studies. In summary, most of the scholars who discuss or mention paratextuality in relation to ancient manuscripts have used the term without a clear definition and have avoided mapping its nuances and limits. But in reality, they do not always include the same elements within the limits of paratextuality and, as we have just seen, there are at least three different tendencies in the underlying understanding of this concept: paratextuality limited to verbal peritexts; paratextuality extended to physical elements such as the layout or certain scribal practices; and paratextuality confusingly describing a relation of imitation or rewriting.

After exploring the notions of "text" and "content" we will come back to the role of the physical features in the definition of "paratexts."

\section{3 "Texts" and "contents" in ancient manuscripts}

The term "paratext" implies a particular understanding of the word "text," whose meaning is notoriously ambiguous. In an article on the paratexts of ancient editions in a bibliographical context, Ugo Rozzo humorously draws attention to this ambiguity: "dovrebbe essere altrettanto evidente che il paratesto non è il testo (anche se è un testo); e dunque si tratta allora di definire cosa sia il testo e cosa il paratesto." ${ }^{47}$ Let us first try to outline some of the different meanings that can be conveyed by the word

44 Ciotti/Lin (eds.) 2013, 8.

45 See note 43 above; including glosses.

46 Similarily, the interesting statements that paratexts "pertain not just to texts but also to their carriers-in our case, manuscripts" and that they are at the "intersection between texts and materiality" (Ciotti/Lin [eds.] 2013, 7) merits further discussion.

47 "It should also be obvious that the paratext is not the text (even if it is a text)," Rozzo 2006, 213. "text" as they appear in the scholarly literature related to manuscript studies. ${ }^{48}$

(a) On a very basic level, any meaningful sequence of words in a manuscript can be called "a text." This sets it apart from (and sometimes in opposition to) other elements such as pictures, drawings, tables, or musical notation. A copy of the Gospel of Matthew, a scribal colophon, the marginal comments left by a reader, and the owner's note on the first page of a codex are all texts with different meanings and functions, and they relate to one another in different ways. This is also what Genette has in mind when he writes, "the literary work consists, exhaustively or essentially, of text, that is to say (a very minimal definition) in a more or less lengthy sequence of verbal utterances more or less containing meaning." ${ }^{\prime 99}$ In order to separate this first meaning of the word "text" from other usages, it can be called here "text-as-words." ${ }^{50}$ Roughly speaking, a "text-as-words" is little or nothing more than some ink on a material support, which expresses verbal meaning.

(b) On the opposite side of the "semantic field," the meaning of the word "text" is sometimes extended to designate any piece of content in a manuscript, even if it is not (or not primarily) made up of words but, for example, of pictures or musical notations. We can call this "text-asany-content.” This inclusive definition results, however, in a systemic difficulty: if "images" can thus designate the subcategory of text (in this very broad definition) consisting of pictures and drawings, what ought we to call the subcategory of text limited to words and sentences?

(c) Other meanings of the word "text" have emerged from the philological tradition. Classical philologists as well as digital editors ${ }^{51}$ working on critical editions of ancient authors (and thus with ancient manuscripts) have established a basic opposition between "texts-as-document," or "text-as-witness"-what they find in the manuscripts-and

48 Other fields, like linguistics, have developed their own approach to this concept. See for example Schwarz-Friesel/Consten 2014, or Scherner 1996.

49 Genette 1991, 261.

50 "Text-as-a-series-of-written-words-with-a-sense” would certainly be more precise as an expression but also more ponderous. What about a series of characters/signs without any discernible meaning (and possibly, without any meaning at all, such as some probationes calami)?

51 As entry points, see Zundert 2015, Sahle 2013, Robinson 2012, Gabler 2010. Interestingly, Sahle presents six meanings of the word "text," in a wheel, whose three main poles are "text-as-ideas-\&intention," "text-as-document" and "text-as-verbal-expression." 
"texts-as-work" or "texts-as-opus"52 - the unreachable original ${ }^{53}$ which the author actually wrote or dictated. This original-or its nearest approximation-is sometimes positioned at the top of a stemma codicum.

The distinction between the texts in a manuscript and the work or opus is important. For example, even though at some point, in half-waking dreams, someone beheld a vision of the Apocalypse and subsequently had this vision transferred to parchment or papyrus, what we have now are some 333 "corrupted copies" of this account, full of variants, mistakes and corrections. These are called "texts-as-witness" because each of them is only one witness-one interpretation I am tempted to say-of this master "text-as-opus." When codicologists try to "identify a text" in a manuscript, they are doing nothing more than putting one supposed "text-as-witness" in a more or less secure relation to a "text-as-opus." In the case of pictures, however, it is usually not possible to speak of an opus/ witness relation because, unlike scribes, artists usually did not try to produce an exact copy of their model (if any); a more nuanced "intertextual" relation is at work here.

It is important to note, however, that these texts, either as "opus" or as "witness," are not necessarily entirely composed of "text-as-words." There are indeed good reasons to believe that some "texts-as-opus" published by Archimedes, Aratus, Aristotle or Nicomachus of Gerasa did not contain just words but also diagrams and graphic representations. For the Bible, Martin Wallraff convincingly argues that in all likelihood the Canons of Eusebius were also originally accompanied by rich decorations, forming an integral part of the opus. ${ }^{54}$ Inversely, many

52 In the English scholarly literature, this basic dichotomy is indicated by various expression like "text" versus "work"; or "document" versus "work"; or even "text of the document" versus "text of the work"; see for example Gabler 2010, 55 n. 1; Robinson 2012, 120 "The text is the site of meaning which links the document and the work" etc. In the French literature, one sometimes finds "texte" versus "œuvre”; see for example Andrist/Canart/Maniaci 2013, 51. This article uses "opus" as a relatively neutral and broadly acceptable term.

53 There is need for caution here for several reasons: first because the term "original" can be a tricky one. To give an example: when Cicero runs to the librarius to correct his manuscripts and all the remaining copies, is it no longer possible to speak of a single original "textas-opus.” The same holds true for Eusebius who published several versions of his Ecclesiastical History: one is no longer dealing with one underlying (and authorised) original text, but several of them. Secondly, in many cases, what is preserved is not the work of a single author, but the result of several layers of "hypertextual activity" as in the Pentateuch or the fourth gospel. Finally, what an author wrote or dictated can also be distinguished from the even more unreachable "text-as-ideas," that is, how he conceived it in his mind.

54 Wallraff 2013, 42-43. images (such as evangelist portraits) contain some verbal elements which identify the pictured saint or contain the opening words of his work; thus here it follows that a "textas-words" is not necessarily part of a "text-as-witness.” In such cases, what was produced by the painter or the scribe, or even composed by the authors, is a mix of verbal and pictorial elements bound closely together. The resulting entity could, strictly speaking, be called a single "imageand-text-as-opus,” or “text-and-image-as-witness." 55

(d) Apart from the philological tradition, one also finds a book-historical usage of the word "text" which is more closely aligned with codicological considerations. For example, even if one does not know the language in which a codex is written, a quick look at the various page layouts usually reveals the likely placement of the titles-that is to say, where the main "text(s)-as-words" are located and, where the "text(s)-as-witness" most likely begin(s). In common usage, sections delimited in such a way are also called texts, but for the sake of clarity let us call them "texts-as-laid-out-content." 56

“Texts-as-laid-out-content" often match "texts-aswitness," but this is not always the case. They also include fluid traditions, where scribes act as authors, and cases of unique production-for example if a piece of content was specifically created for one prestigious book, such as a new book-epigram or a specific dedicatory introduction. ${ }^{57}$

55 Traditional collections of "text-as-opus" (or extracts thereof) also raise special problems that lie beyond the scope of this essay; see Maniaci 2004, 82-90 and also Andrist 2016c, 18-21, where the question of biblical manuscripts as syllogè is briefly set forth.

56 Strictly speaking, these are generally meant to be "texts-as-laidout-verbal-content."

57 There are also other cases where "texts-as-laid-out-content" do not coincide with "texts-as-witness." This might occur, for example, when-due to an error (according to current philological thinking, but one should also consider whether it could not be a conscious change in the tradition)-a scribe did not divide the written material at the customary place between two "texts-as-witness" or when a material accident takes place in the transmission of a book, or even when a series of "texts-as-witness" are read in an alternative way. The "textbook" example of this phenomenon occurs in the Codex Sinaiticus, where, in the middle of a line, the scribe "jumps" from I Par. 19,17 to II Esdr. 9,9 (see Parker 2010, 65-67). However, since each part of the resulting single "text-as-laid-out-content" is a discontinuous witness to one specific "text-as-opus," this "text-as-laid-out-content" can still be analysed as two fragmentary "texts-as-witness." Similarly, a "text-as-laid-out-content" might include a copy of an "opus" as well as the adjacent colophon found in its model, especially when these two pieces of contents are not clearly differentiated by their layout. Inversely, a philologist might claim that, due to peculiar ways of splitting and grouping "texts-as-witness," a codex may present a greater number of "texts-as-laid-out-content" than there are actual 
Similarly, they also cover any clearly delimited textual unit in the margins of a manuscript, such as, for example, a marginal scholion. At this point we hope to have shown that the content of a codex is composed of an articulated series ${ }^{58}$ of "pieces of content" whose nature varies according to the greater symbolic system to which they belong (words, musical notes, shapes and colours, etc.). Additionally, each piece of content can be made up of any number of elements which may equally vary according to their main symbolic system. ${ }^{59}$ Secondly, we have also seen that they may vary according to their dependence on (or independence from) a specific textual tradition. As we shall see, paratextuality reveals a third type of difference between the various pieces of contents.

The physical way in which the pieces of content are rendered in a manuscript should not be confused with the pieces of content themselves, even if the form can influence the reception (and sometimes the interpretation) of the message, i.e. the meaning of the pieces of content. As will be explained in the next chapter, material support, quires, layout, ink, decoration and other such things are also able to convey important messages but they usually do not belong to the direct or primary meaning of the text or the images in the codex ${ }^{60}$ (even though these two types of meanings can interact) and are not included in the content of the manuscript. Similarly, written elements such as folio numbers or quire signatures are technical tools closely linked to their corresponding physical features (pages, quires, etc.), and do not have any direct relationship with the meaning of the pieces of content. This is why they are a part of the physical language of the codex ${ }^{61}$ and are not to be designated as pieces of content. ${ }^{62}$

\footnotetext{
"texts-as-witness." For example, the first production unit of Bern, Burgerbibliothek, 459 (Diktyon number 9563) presents 4 "textsas-witness" from the corpus Rufianum: De nomenclatura corporis partium; Epitome de nomenclatura corporis partium; De anatomia corporis partium; De ossibus. However, according to the mise-en-texte of these witnesses in the codex, there are only 3 "texts-as-laid-outcontent": a) the first part of the De nomenclatura corporis partium; b) the second and last part of this same text; c) and then, the three last "texts-as-witness" clumped together as a single "text-as-laid-outcontent."

$\mathbf{5 8}$ "Series" is always meant to include the unusual case of only one element.

59 Again, for example, an artist can chose to incorporate many verbal elements in his pictures; or an author can include diagrams or small pictures in his opus, which are then more or less well transmitted by the scribes.

60 Exceptions could be visual poems, or calligrams such as the $S y$ rinx of Callimachus.

61 See below, p. 139.

62 This stands to reason: If a page in a manuscript has nothing written on it, we say that it is blank or empty. If a page contains only
}

In the preceding paragraphs, we have briefly explored the complexities of using the word "text" to describe a piece of content in a manuscript and the confusion that can easily attend this designation. For the purposes of the present study, then, it seems preferable to limit the word's sense either to "text-as-words" or to pieces of content mainly made up of words (the "mainly verbal category" of the pieces of content), while "images" will be applied as a generic name for the "mainly graphical category."

(e) Finally, the word "paratext" implies one further meaning of the word "text" which is encapsulated in the above-mentioned quotation by Ugo Rozzo, that "the paratext is not the text (even if it is a text)." On the most basic level, a paratext is a piece of content whose presence in the codex directly depends, as far as its meaning is concerned, upon another piece of content, which we suggest to call its "protext." It might draw on the structure or one of the main themes of the protext, ${ }^{63}$ discuss the style or touch upon a small detail, but there must be an "internal" link between the two pieces of content. Theoretically speaking, if one were to take a paratext out of a codex, the protext would in most cases still make sense. But the inverse does not hold true: if the protext is removed from a manuscript, in most of the cases the paratext would make little sense alone.

Consequently, in a manuscript a paratext represents a piece of content which distinguishes itself from other pieces of content on the basis of its subordinate position in the greater scheme of the overarching book project, an idea we will revisit in section 2.2. Genette's theory is based on the idea that not all the pieces of content in a printed book possess equal importance in the eyes of the author. The same is true of manuscripts, the criteria being, in this case, the book itself and the book-making traditions (and not, of course, the reader's whim). The most basic distinction is the one between a book's "core-contents"-the pieces of contents that form the core of the book's project theme(s) - and their paratexts. A third type of content consists of small pieces which we call "side-contents," without obvious connection to the book's project theme(s). Sometimes they were added incidentally and we also find them, for example, as "bouche-trous" (filler)-we will revisit these again below. It should be noted that there are cases were side-contents can also be protexts.

In this brief overview alone, we've already come across at least seven direct or implicit uses of the word

a folio number, most would agree (and correctly so) that it still is an empty page.

63 On the concept of "theme/thematic," see Andrist 2016b, 22-24. 
"text." ${ }^{64}$ As such, it is important to be cognizant of the word's high degree of polysemy and to guard against the confusion and misunderstanding which this polysemy is liable to produce in scholarly discourse.

\section{4 "Physical features" and paratextuality}

As our bibliographical survey has shown, if one leaves aside the "revivalist" use of the concept of "paratext," the main difference between the two others "poles" of meaning has to do with the way physical features are treated. Why should features like the script or the layout or the writing support not be considered genuine paratexts? Genette would consider them paratexts, after all. Several other printed-book historians have also included all physical features of a printed book in the realm of paratexts, to the extent that sometimes the content (= the text) stands in opposition to the container (= the paratext)! ${ }^{65}$ Do they not mediate between the readers and the main content? Why should the category of "paratext" be limited to pieces of content?

There are several reasons for this. Firstly, (most of) the physical features of a book are essential to the existence of its pieces of content (either core-texts or paratexts). As such they are very different from the (content) paratexts which can theoretically be retrieved from the codex without a priori modifying the core-content. Although it doesn't cover every possible case, Gilles Dorival's remarks ${ }^{66}$ concerning the preparatory physical features such as ruling remind us that (most of) the physical features are a sine qua non for the books' existence (including its content).

64 "Texts-as-words,” “texts-as-witness,” “texts-as-opus/-work," "texts-as-any-content," "texts-as-laid-out-content," "texts-as-corecontent," "texts-as-ideas."

65 In addition to the cases mentioned above, see also for example, Castiglioni (2005), who considers elements such as the paper and its colour, the layout, the typographic characters and the binding to be paratexts; see also Biancastella/Santoro/Tavoni 2004, 141 on the "livres d'artistes" from the early twentieth century: "Tali esperienze preludono al livre object, che assume dalla tradizione la sola veste esteriore, rinnova materiali e funzioni, ribalta la preminenza del contenuto (testo) sul contenente (paratesto)."

66 As quoted by Brooke, see above note 35. See also the remark by Rozzo 2006, 213-14: "Ma, a mio avviso, senza moltiplicare le invenzioni terminologiche, anche al fine di evitare confusioni, si tratta semplicemente di precisare che l'insieme delle componenti materiali del libro (carta, caratteri, ecc.) non possono essere considerate paratesto, sono solo i supporti attraverso i quali il prodotto o l'oggetto/libro esiste."
Secondly, in contrast to Genette's printed editions, the antique and medieval manuscript book is an unique object whose cultural relevance and importance reach beyond its content, no matter how important its texts are or how humble its materiality is. A codex is much more than just a vehicle for texts and images. It is always a witness of the people who ordered it, of those who produced it (and the techniques they used) and of the people who used it. As an object, it can also convey (among other things) political, aesthetic or spiritual meaning. There are even cases where it is likely that the primary objective in producing a manuscript book was not to create a copy of the content or to have this content be available for reading and circulation. ${ }^{67}$

Thirdly, in Genette's view, an author (or a person authorised by the author) is in control of all the elements surrounding the publication of his text and the printing of its many copies. His text is at the centre of the project and the publication is entirely in service of the text. But this was certainly not the case in the production of most medieval manuscript books.

It is worth remembering that the producers of a medieval manuscript book usually had no contact or authorisation from the authors of the core-texts (or even the authors of the paratexts) they wished to include in their book. As such, the patron (or the person responsible for the book) was often able to choose the core-contents and the paratexts with a given measure of freedom and the result was a unique object.

Regardless of the book producers' wider goals, the physical making of this unique object (including all the physical features) was a crucial and necessary component of the larger book project. While a book's content usually played a major role in the decision to create a book as well as in its planning and production (it was often even the decisive factor), other factors can and should not be discounted. Cultural standards, book-historical practices, particular local circumstances, practical requirements all equally played their role in producing an object which was, in each case, an original artefact with its own particular historical signification (see below). It also happened on occasion that the main project goals of the book producers had little or nothing to do with the meaning of the written texts or images.

The importance of the content in determining a book's physical features should, then, not be overstated. When a

67 For example, in a forthcoming study Martin Wallraff discusses luxury Gospel manuscripts with basic errors in the Eusebian canon and apparatus and calls into question whether these books were actually meant to be used, or even read (Wallraff, forthcoming). 
manuscript's physical features are thus reduced to paratexts or paratextual functions-meaning that their only possible raison d'être is to be a vehicle for the content of the book-the book project's larger cultural signification remains overlooked.

Fourthly, a medieval codex, it must be remembered, is an evolving object. In its present state it is often the result of several book projects whose complexity and individuality often become apparent only when the book's physical features are correctly understood and sufficiently considered.

Thus, the physical features of a current codex are "like a language with its own rules, made of small significant details, recurring elements and more or less important discontinuities. When understood properly, this language informs the readers about the stratigraphy of the codex and, ultimately, its history." 68 This history (which takes into account both the "genetic" and subsequent historical phases of the codex) includes the various projects which the constitutive elements of the book were once part of, as well as (among other things) their cultural and social significance (and importance) at any stage of its life. ${ }^{69}$ This broader approach to the manuscript book does not rule out that some aspects of the physical features (the layout, the ink, the script etc.) can play a special mediating role between the main content and the reader. Since the secondary paratextual functions of a manuscript book's physical features operate on a different level than the relationship between primary paratexts (i.e. pieces of content) and their related core-content, we prefer to speak of these physical features in terms of their "paratextual dimension" or, to borrow a term from chemistry, their paratextual "valence." For example, when thinking in these terms, we might posit that when standard ink is used to copy out a text, this ink does not possess any specific paratextual function other than the fact that it allows for the text to be read. The paratextual valence of this ink in this particular book is thus null. If, on the other hand, the text is fully copied out in a resplendent golden ink on purple parchment, it certainly influences how the reader looks at the text (besides an obvious message about the wealth and social status of the patron, and, in some cases, his mauvais-goût). In such a case, the paratextual valence of the ink is certainly important.

68 Andrist 2015, 520 (see also pp. 513-14, 521-22, and Andrist/ Canart/Maniaci 2013).

69 The marked advantages of this broader approach become readily apparently when dealing with cases where one has multiple copies of the same content, as is the case for biblical manuscripts.
The literature cited above shows that even those scholars who consider physical features to be paratexts ${ }^{70}$ spontaneously make a basic but major distinction in their vocabulary between elements like titles and accompanying epigrams (whose primary purpose in the book is directly related to its main content) and elements with paratextual valence (whose chief purpose lies in their relation to the book object).

To conclude this section, we suggest that the definition of paratexts in manuscript books be limited strictly to the realm of content, to the exclusion of their physical features, even if the paratextual valence of the latter can play an important role in determining the paratextual effects or strategies at work in a book and in more general discussions of paratextuality. The analysis of a manuscript's physical features should never be reduced to their potential paratextual valence. ${ }^{71}$

As a result, a paratext would simply be a piece of content which is thematically dependent on another piece of content in the same book.

\subsection{The concept of "producing" an ancient manuscript book}

In our present day (as well as in Genette's theoretical system) the concept of "publishing" is strongly linked to that of an author making a "text-as-opus" public, that is to say, potentially available to other people. In the world of ancient manuscripts, ${ }^{72}$ producing a book (encompassing both the content and physical features) was a privileged way of potentially making texts (and/or music and images, etc.) available to oneself or to other people in a lasting way. According to the most common scenario-though there are exceptions to be found-the book producers (including all who were responsible for the book's form and its contents $)^{73}$ had no direct contact with the author(s) of the books' content, who usually lived long before them, as

70 For example, see above p. 134.

71 Similarly, the analysis of paratexts or of the physical features should never be reduced to a codified method for "dating and locating" the manuscript as this fails to do full justice to the initial or subsequent production projects which it helps uncover.

72 Basically, before printing was established as the main tool for circulating texts and images. This does not mean, of course, that none of the following remarks apply to subsequent periods.

73 This often, but not necessarily, implies a patron, a scribe and a book-binder, and includes cases where the responsibility for the entire process was held by a single person. 
we have already mentioned above. ${ }^{74}$ This scenario breaks away from the pattern outlined by Genette.

Producing a book is not the same thing as producing a copy of a text. ${ }^{75}$ If they so wished, the producers could make a new book by putting together all its constitutive elements from already existing manuscripts without producing any new "text-as-witness." ${ }^{\text {"76 }}$ When one sets down some content in writing on a wax tablet or a sheet of parchment, this means that the content is fixed and preserved for a period of time. Producing a manuscript book (a scroll, a codex, a "leporello," etc.), however, either from scratch or from reused materials, transforms this act of fixing content into something much more durable. In this form, the content is easily shared and transmitted and, if conditions are right, can be preserved almost indefinitely.

Thus the concept of "producing" a manuscript book has much in common with "publishing" a printed book. ${ }^{77}$ In this essay, "producing a book" designates the process by which a manuscript book is conceived and physically created. It encompasses all the stages between the original ideas about the book until its completion, including all the decisions about its content, its layout and its physical realisation. In short, it includes all aspects of the intellectual and physical project that underlie the creation of every book.

If one sees the producers of a manuscript book as the pre-modern equivalent of the author and the publisher of a printed volume, the concept of paratextuality (as outlined by Genette with reference to the printed literary book) can be meaningfully transposed onto the medieval manuscript book. Thus, Richard Macksey's summary (quoted above) can also apply to manuscript books because also

74 Painters are the exception to this, of course. This can also be the case for some pieces of content such as epigrams: one cannot exclude that the book-producers may have been personally acquainted with their authors, or even commissioned these small pieces.

75 In structural codicology, the result of producing a book is a new Circulation Unit, while the result of producing a copy of a text is a new Production Unit, which might also be a Circulation Unit. On these important concepts, see Andrist/Canart/Maniaci 2013, 59-61, 79-80.

76 For some examples of NT manuscript books re-using parts of previous ones, see below p. 144.

77 Several earlier attempts of mine to transpose the word "publish" directly to the world of manuscript studies resulted in a great amount of misunderstanding by friends who acted as proofreaders and exposed how much confusion can arise from unexamined assumptions. (For these friends' frank and helpful criticism I am very grateful.) The same difficulties arose with the concept of "editing," in spite of expressions such as "editorial practices" as used by Eric Scherbenske (see Scherbenske 2013). The term "manufacture” was equally weighed and found wanting. in manuscripts, paratextuality comprises "those liminal devices and conventions ... that mediate the book to the reader."78 This is what the current essay now sets out to explore within the paratexts of Greek New Testament manuscripts.

\section{Paratextuality in the Greek New Testament manuscripts}

\subsection{The corpus of Greek New Testament manuscripts $^{79}$}

According to the website of the Institut für Neutestamentliche Textforschung, 5560 manuscript witnesses to the Greek New Testament are known today, ${ }^{80}$ in addition to an unknown number of ostraca and amulets. These manuscript witnesses-sometimes just tiny fragments-date from the second to the nineteenth century. They were almost exclusively copied as codices of many different types. Their main categories are:

(1) Books containing New Testament "texts-as-opus" as their only core content, in the traditional order (see category III). This includes the two main types of books into which the New Testament was traditionally divided in the Greek Orthodox and related churches:

- Tetraevangelia, containing the four gospels;

- Praxapostoli, containing the other canonical texts, often without the Book of Revelation. More rarely (but not altogether uncommon), all the canonical texts of the New Testament (sometimes even all the canonical texts of the Christian Bible) are found in the same volume. These New Testaments or full Bibles were sometimes completed as part of a later restoration (i.e. a different scribe, at a later stage, would supplement the extant material with additional texts) or were produced out of several separate volumes containing single biblical texts or groups of texts. ${ }^{81}$

78 See above, p. 131.

79 Among the abundant literature, see as possible entry points Ehrman/Holmes (eds.) 2014, Parker 2008, Dupont-Roc 2008.

80 Data verified on 21 June 2016: 131 papyri, 286 majuscules, 2783 minuscules, 2360 lectionaries.

81 In order to avoid creating confusion, we do not use the expression "biblical books" in this essay. The polysemy (and thus ambiguity) surrounding the use of the word "book" is a question that merits further investigation. 
(2) Books containing New Testaments texts accompanied by commentaries. From a book-historical perspective we may distinguish between two main types:

- Manuscripts with a standard layout, where the biblical pericopes alternate with their relevant commentaries in the main body of the text. These can be, for example, commentaries by a single author or complete biblical chains. ${ }^{82}$

- Framed chain manuscripts, where the main written space contains the biblical text and is framed by related chain commentaries (side glosses) mostly on the three external sides.

(3) Liturgical books (particularly lectionaries) containing the text of the New Testament divided into short sections and arranged for use in the Greek Orthodox liturgy. They are often grouped together according to the same book types as in category I.

We should also mention that in some ancient biblical manuscripts, copies of (what is traditionally considered) the canonical New Testament texts sometimes circulated alongside (what are traditionally considered) noncanonical texts, also copied as main contents.

Our remarks below are based on a representative subset of books drawn from the first category mentioned above (including also framed chain manuscripts) which date through the end of the sixteenth century. ${ }^{83}$

\subsection{Book producers' paratexts in Greek New Testament manuscripts}

As with any other book, every codex of the Greek New Testament is the result of a book production project and process

82 Dorival 2014; among many possible titles see also Dorival 19861995 and, for non-biblical "chains," Maniaci 2006. Basically, biblical chains are a consciously arranged and transmitted series of patristic commentaries on small biblical units (often a verse) in the order of the biblical text. As a result, they should not be seen as a long series of small paratexts to the Bible, but as a single "opus," whose materialisation in a manuscript is a single "text-as-witness." Chains must not be confused with the scattered marginal commentaries added freely by the scribe, which are non-traditional book-producers' paratexts. Of course, if the scribes begin reproducing these scattered commentaries systematically, they might soon also become traditional paratexts; see below.

83 This is also traditionally the chronological end point of Greek manuscript studies, since after the sixteenth century manuscripts (apart from certain exceptions) ceased to be the main vehicles for Greek works in general and the Bible in particular. which usually (but not always) had as its main objective the copying of biblical texts. ${ }^{84}$ In addition to the biblical witnesses which form the core piece of content of these manuscripts, the producers also (almost) always ${ }^{85}$ included paratexts like prologues or capitula. From the producers' point of view, these paratexts were entirely in service of the book's theme, since their raison d'être is (to put it in modern terms) to help mediate the biblical content to the readers. ${ }^{86}$ They can be called "book producers' paratexts" and must be distinguished from "post-production paratexts" (see below).

Thus, when analysing the content of any manuscript, the most obvious and objective distinction which can be made is the following: on the one hand there are the pieces of content (including the paratexts) which belong to the book as it was produced-their presence in this book results from the same project-and on the other hand, there are the pieces of content which were added later, such as notes by a reader or an owner. When making this distinction, we do not mean to imply that post-production paratexts are in and of themselves less interesting than book producers' paratexts or that all paratexts within each of these two groups are similar. On the contrary, they can be grouped in various categories, as we shall attempt to do now.

Firstly, these are the categories of book producers' paratexts that we have found in Greek New Testament manuscripts:

(a) A first category covers the content which is very frequently found around the biblical text, and we call this "traditional paratexts." Various types of traditional paratexts can be identified.

First, scholars agree that titles such as "The Gospel According to Matthew" were neither given by the Gospel's author, nor invented by the Byzantine scribes or producers; they had to write a title just before each biblical text begins. ${ }^{87}$ Though bound by firmly-established traditions,

\section{See above, p. 138.}

85 On very rare occasions, a biblical manuscript may contain none of the expected paratexts (except for the titles). See for example the tetraevangelium Jerusalem, Patriarchikî Bibliothîkî, Panagiou Taphou, 46, described by Sergey Kim in the ePTB/Pinakes database (Diktyon number 35283; cf. Gregory Aland number 1318) for the ERC ParaTexBib project.

86 This dimension of medieval book making seems to have escaped Genette completely; see Genette 1997a, 16; 1984, 21: "But what the pre-Gutenberg period did not know anything of-precisely because of the handwritten (and oral) circulation of its texts-is the publisher's implementation of this peritext, which is essentially typographical and bibliographical in nature."

87 We also fairly often find titles at the end of the biblical texts. The precise origin of the titles of the New Testament books is unknown, 
the producers still had a certain amount of leeway to make small changes to the titles. As a result one still finds a series of variants, mostly involving adjectives qualifying the holiness of the attributed author and/or his opus. Let us call this kind of paratext "mandatory traditional paratexts" or, in full, "mandatory traditional book producers' paratexts."

The strength of the tradition varies also according to the type of paratext and the historical context of the producers. In many cases, the producers enjoyed a certain amount of freedom to include or omit a specific paratext, mostly texts-as-witness. But, as far as the textual content of these paratexts was concerned, there was much less freedom because they were bound to their own textual tradition. For example, some producers might choose to include or omit the Canons of Eusebius or the Letter to Carpianus in a tetraevangelium in accordance with the purpose of their book and their preferences. If they did so, however, they could not significantly alter the contents of these "texts-as-witness." In this sense, this type of traditional paratexts can be said optional (or "optional traditional book producers' paratexts"). ${ }^{88}$ Other examples of traditional paratexts are the capitula lists and divisions, liturgical tables or the liturgical indications in the margins of the biblical text. We also include in this category the traditional painted material like the Evangelist portraits.

These traditions were liable to vary and evolve rapidly according to place and time-unlike the biblical text, whose textual tradition was much more resistant to change. In an abundant corpus such as the biblical Greek manuscripts, it is, however, easy to see what was is optional and what is mandatory, and what are the exceptional cases. But one must also be aware that the traditions that make a paratext mandatory in a specific cultural context might be different in other contexts, where this paratext is not mandatory. Additionally, in smaller corpus these kinds of nuances might be impossible to see.

(b) In other cases, however, the producers included some unusual material (that is, unusual within the tradition of New Testament manuscripts) such as epigrams, paschal tables, or exceptional prologues or paintings. The presence of these pieces of content in a codex appears to be the

but it is early, as they are already found in some second century witnesses. On the question of the titles, see the forthcoming book by Emanuele Castelli.

88 Again, "optional" in the sense that they could choose not to include them in their book-in contrast to titles, which were required; "traditional" in the sense that it is quite usual to find titles, capitula and Eusebian canons. result of a deliberate decision on the producers' part. We might mention, for example, the tetraevangelium Athos, Hagion Oros, Monê Philotheou $21,^{89}$ which begins with no fewer than 35 folios containing all kinds of paratexts, including excerpts from homilies of John Chrysostom, various indices, and brief explanatory pieces. The Psalter, Oxford, Bodleian Library, Auct. D.4.1, containing Eusebius's Canon of the Psalms, ${ }^{90}$ is an even clearer example, though from the realm of the Old Testament. These are also producers' paratexts but belong to a different category which could simply be called "non-traditional paratexts" (or, in full "non-traditional producers' paratexts"). Even in light of a specific cultural context, the difference between traditional and non-traditional should be seen as a continuum between two poles. Our current studies try to determine whether the degree of "traditionality" of a specific paratext depends on historical factors such as geographic location, chronological period, or even more book-historical related factors, such as the overall aesthetic of the book (luxurious, simple ..., its intended usage (liturgical, private ..., or the religious peculiarities and religious traditions of the producers (the customs of their monastery, their involvement in religious debates ... Even though the relative weight of these factors cannot yet be correctly evaluated, it is still possible to tell when a specific paratext is very traditional or less so.

(c) Often, in a biblical manuscript, there can be various types of written elements which are added by the producers and do not belong to the tradition of any opus, such as signs placed in the margins by the scribe in order to call the reader's attention to a certain part of the core text or internal revisions added by the scribe or a reviser before the book left the place it was copied. ${ }^{91}$ These are very closely linked to the content of a specific book and, in the light of the equivalency discussed above between printed book publishers and manuscript book producers, we call them "manuscript producers' paratexts," building on a suggestion by Liv Ingeborg Lied.

How should we analyse a scribal colophon? They are, without a doubt, pieces of content which belong to the book but do not form part of its core texts. ${ }^{92}$ Are they paratexts? Strictly speaking, they have no direct connection to

89 Lambros 1784. See the description by Sergey Kim in the ePTB/ Pinakes database (Diktyon number 29385; cf. Gregory Aland number 1118), for the ERC project ParaTexBib.

90 Diktyon number 46972. See Wallraff 2013, 5, 8-9.

91 They should not be confused with "re-made book paratexts" or "sacred book producers' paratexts," which are briefly presented below.

92 This is also true if they are copies of another older colophon. 
the biblical theme of the book (in many cases the colophon would not be different if the core content were non-biblical), and apart from certain exceptions they also do not help to mediate its message. From this perspective they might be viewed as (small) secondary core contents or even side-contents (see above). In another sense, however, they are thematically linked to the core content because the theme of the colophon is related to the core-content inasmuch as it refers to the crucial act of bringing it into material existence (for example, when it was produced, by whom, or under what circumstances). In any case, they are very closely linked to the production, and we consider them another type of "manuscript producers' paratexts." 93

When a scribe attaches a religious epigram or a prayer to the end of a biblical text or the codex, what he adds is not necessarily dependent on any specific biblical passage or opus. We still consider it a paratext, however, because it contributes to the overall sacred character of the book, which can be placed in direct relation to its core-content. This is another type of manuscript producers' paratexts.

But what about framed chain manuscripts? ${ }^{94}$ In a recent article, Gilles Dorival analyses the relationship between scholia and the commented text as both metatextual and hypertextual. ${ }^{95}$ But is it also paratextual? On the one hand, one can argue that, as a unit, the sacred text and its glosses represent a witness of a broader, more complex "text-as-opus." On the other hand, chains are clearly paratexts, since they lose their relevance when separated from the corresponding biblical "texts-as-witness." The reverse is certainly not true: if a manuscript of the New Testament with a chain were stripped of the chain, the biblical text would be able to stand and be read on its own. Furthermore, chains evolve at a much faster rate than the biblical text, since the scribe has often taken it upon himself to edit or condense certain glosses. We will return to this shortly, ${ }^{96}$ but the fact that chains are paratexts should not prevent anyone from also viewing and analysing the resulting content (biblical text + chains) as a single witness. In fact, both types of analysis (on the one hand, examining the biblical text and the chains in a codex together as one single text and, on the other, as two pieces of contents linked by a paratextual relation) reveal complementary aspects of the complex structure and history of these kinds of intricate book contents.

93 The same is also true if a colophon mentions the name of a painter. 94 About chains, see above, n. 82.

95 Dorival 2014.

96 See below, p. 146.
It should be noted that many of the pieces of content in the above categories b) and c) are both autonomous witnesses to a specific author, such as Eusebius or Euthalius, and also paratexts, because they do not belong to the core content of the book. In the Codex Alexandrinus for example, before the Psalms we find Athanasius's Epistle to Marcellus and Eusebius's Hypothesis to the Psalms, which are thematically connected with the Psalms. According to the philological tradition, the Codex Alexandrinus is a witness to those "texts-as-opus," while from a book-historical perspective they are also paratexts to the Psalms in a biblical pandect.

At this point a few important questions need to be addressed. In our biblical manuscripts, is there such a thing as authorial paratexts according to Genette's definition? ${ }^{97}$ In one sense there are some; the prologue of the Gospel of Luke (Luc. 1,1-4), for instance, can technically be considered an authorial paratext. This instance, however, falls within the purview of text historians. ${ }^{98}$ Both in the present day as well as at the time when the codex was produced, this section is considered an integral part of the author's opus and, from a book-historical perspective, it is not a paratext since, in the manuscripts, it never appears as a separate piece of content.

Secondly, should the images in a New Testament codex also be considered paratexts? One often finds paintings in tetraevangelia, such as evangelist portraits or representations of the Nativity or the Resurrection. As we have discussed above, insofar as these graphic entities can also be considered pieces of content, they are paratexts. ${ }^{99}$

A third and related question has to do with the limits of graphic elements as paratexts. At what point should a graphic element no longer be considered a paratext but a decoration? And, inversely, when should a beautiful non-figurative headpiece or initial be described as a paratext? Again, without denying the paratextual valence of these physical features, their possible social, book historical and other possible significations ${ }^{100}$ have to be distinguished from the intended message(s) of the pieces of content. As a result, non-figurative decorative elements cannot a priori be considered paratexts.

97 See above, p. 131.

98 Incidentally, it alludes to an additional definition of the word "text." 99 See above, p. 137. It may seem awkward to call an image (with or without a caption) a paratext, and I once suggested replacing "paratext" with the word "para-content" at least in technical discussions. However, the suggestion was not widely adopted and it is perhaps simpler to continue with "paratext," extending the term to include non-verbal content.

100 See above, p. 139. 
Fourthly, are all pieces of content in a manuscript book either core-content, paratext or side-contents? Yes, from our perspective, with the exception of contents on reused material such as the scriptura inferior of palimpsests, which are pieces of content "in" but not "of" the book, if one wishes to express it this way. However, the analysis of core-contents must also accommodate differing degrees of complexity. For example, when the vast majority of a book's core-contents is thematically coherent ("homothematic") but there are also a few pages in the same codex of mostly "heterothematic" material. ${ }^{101}$ How can we explain such a situation when both the homothematic and heterothematic elements clearly belong to the same original book project? Seeing that the contents on these few pages differ thematically from the other contents, it is difficult to posit a paratextual link between them. But, since the heterothematic contents were produced at the same time as the homothematic contents, these must also belong to the core-contents of the codex, though not as principal core-contents but as secondary core-content. ${ }^{102}$ In the case of New Testament manuscripts this situation is very rare, most probably because in the book tradition of tetraevangelia and praxapostoli ${ }^{103}$ there was no "conceptual space" to publish secondary core-texts.

Inversely (and as mentioned before) it frequently happens that a new book is produced from the remains of an already existing one (or part of it) by adding or modifying some elements. For example, in Città del Vaticano, BAV, Vat. gr. 363 a later hand added both the liturgical tables at the beginning of the book and the apparatus liturgicus in the margin of the biblical text, which resulted in a tetraevangelium which was coherent according to the traditions of the New Testament manuscripts and was different from the previous one. ${ }^{104}$ We call such altered

101 On the concepts of "homothematic" and "heterothematic" see Andrist 2016b, 38; see also Andrist 2012, in particular about the concept of "quasi full book."

102 For an introduction to and further explanation of the concept of principal and secondary thematics in a book and the distinction between them, see Andrist 2016b, 22-24.

103 Cf. above.

104 See the description by Agnès Lorrain in the ePTB/Pinakes database (Diktyon number 66992; cf. Gregory Aland number 132), in the frame of the ERC ParaTexBib project. A similar but not quite identical situation occurs when people producing a new book reuse already circulating texts for a small part of it, as in the manuscript of Sofia, Naučen Centăr za Slavjano-Vizantijski Proučvanija "Ivan Dujčev," D. gr. 177 (olim Serres, Monê tou Prodromou, membr. A' 2; Diktyon number 62431; cf. Gregory Aland number 1684; see again the description by Agnès Lorrain in the database ePTB/Pinakes), where, if our analysis is correct, book producers of the twelfth century copied a tetraevangelium but reused a liturgical table from the second half codices "re-made books." 105 The remaking of a book is often (but not always) linked to its restoration.

\subsection{Post-production paratexts in Greek New Testament manuscripts}

What is the situation with respect to later, small supplementary texts, including notes by a reader or an owner? Is there space in this approach for paratexts added after the book was produced?

The answer is affirmative and relies (as explained above) on the major distinction between the pieces of contents produced by the producers, which are the result of a more-or-less coherent project, and the contents which were more-or-less haphazardly added to it at a later stage. However, as we will see, not every added piece of content is necessarily a paratext.

Let us now move forward and discuss the various categories into which we can divide post-production contents:

(a) The elements of content (often small notes in the margins of the book) which correct, supplement or comment upon the adjacent part of the core-content or the producers' paratexts (like corrections to the biblical texts or the capitula). They might also provide new content relating to one or several of the biblical texts, such as a new prologue on an empty page. As such, they are directly or indirectly linked to one of the themes of the book. They could somewhat loosely be called "readers' paratexts" (or, in full, "readers' post-production paratexts"). A wellknown example of such a paratext occurs on p. 1512 of the codex Vaticanus (Città del Vaticano, BAV, Vat. gr. 1209) ${ }^{106}$ : here we find a marginal note voicing its disapprobation of a variant reading in Hebr. 1,3, "Fool and knave, can't you leave the old reading alone and not alter it!"107

There are, of course, grey areas. For example, are the paschal tables added to the tetraevangelium Genève, Bibliothèque de Genève, grec 19 "reader's paratext" or "remade book paratexts"? ${ }^{108}$ At first glance, they seem to belong to the realm of re-made book paratexts rather than

of the eleventh century. This kind of phenomenon seems to be fairly frequent.

105 It has sometimes been called a "second edition." 106 Diktyon number 67840; cf. Gregory Aland number 03.

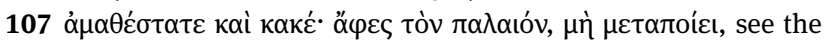
presentation by Didier Fontaine on areopage.net/blog/2013/07/04/ hebreux-1-3- $\varphi \alpha v \varepsilon \rho \omega v$-ou- $\varphi \varepsilon \rho \omega v$ (accessed 16 November 2017).

108 See the description by Agnès Lorrain in the ePTB/Pinakes database (Diktyon number 17169; cf. Gregory Aland number 75). See also Andrist 2008, 440. 
that of reader's notes since the supplementary material, written on more than one added page, applies thematically to the whole book (or at least a large part of it).

(b) Are post-production contents such as owners' notes to be considered paratexts? This question picks up on several of the points that we previously discussed in relation to colophons: on the one hand, when an owner decides to put his name, and nothing else, on all his books, the added content has no thematic link to any of the books. Such a note would then be little more than a piece of "post-production side-content." On the other hand, however, one can argue that such a note provides important information about the book's history and is thus able to mediate the book's content to its users, especially if the note specifically mentions the name of the book or the title of its main piece of content (a common example is "this tetraevangelium belongs to ...”). In order to simplify the nomenclature, we consider them "book paratexts" (or "post-production book paratexts").

Another type of book paratext covers those not infrequent cases where a piece of content is added in a Bible, not with reference to a specific biblical book or verse, but simply because it was considered a sacred book. In this category we find, for example, obits, hymns and prayers added on the last page or on the fly-leaf. Again, instead of considering them "post-production side-content" we prefer to place these in the category of "(post-production) book paratexts" as well. In contrast to prayers and religious epigrams, they do not increase the sense of sanctity conferred upon the book by the biblical text, but depend on it. It could also be termed "sacred book paratexts."

The above-mentioned supplementary or reused ${ }^{109}$ texts appearing in a re-made book present a special situation. They might well be called "re-used paratexts" in light of their double role in both the original and the new book projects. But in relation to the re-made book, they simply act as constitutive book producers' paratexts. ${ }^{110}$

Can we thus reach the conclusion that all (or any) supplementary material can be seen as a paratext? Unfortunately not, because one sometimes finds supplementary written materials which have absolutely no thematic link either with the main contents of the book or, more locally, with the adjacent material. This is the case, for example, when we find the first words of the Iliad being used as a probatio calami on the initial fly-leaves of a tetraevangelium in Jerusalem, Patriarchikî Bibliothîkî, Timiou

109 See p. 144, including n. 104.

110 The same can be said about the main content.
Stavrou 95. ${ }^{111}$ This clearly isn't a paratext but it is still a piece of content. It definitely fits the category of "post-production side-content."

Another example we could mention (which is also a borderline case) is taken from the tetraevangelium Cologny (Genève), Fondation Martin Bodmer, Bodmer $25 .{ }^{112}$ At a certain point, the book was re-made through the addition of a new production unit containing liturgical tables. Then, at a later stage, an extract from the De mensuris et ponderibus by Epiphanius was added to the end of the liturgical tables. Thus, in a sense these supplementary lines from Epiphanius could be considered a piece of post-production side-content. But they also give glosses for technical terms like "talent" and "stater" which are used in Matth. 25 and Matth. 17 and, as such, could also be considered a post-production paratext to the Gospels. This example underscores the nature of the paratexts: they are paratext not by virtue of their content or position in the codex, but by thematic relation to one or several other pieces of content of the book. Now, if non-paratextual supplementary material is modified by a later user, this modification is still a paratext even though its protext is not thematically linked to the main theme of the book. ${ }^{113}$

A last example should warn us about the misleading impression that the position of a text could give about its paratextual nature. The portrait of John and Prochoros on f. $265 \mathrm{v}$ of the codex Basel, Universitätsbibliothek, AN IV $2^{114}$ is an image paratext to the Gospel of John, which begins on the opposite page. Beneath the image, a later hand added the following epigram: "The lion, who is the model of strength and courage, prefigures Christ the King, as all-powerful."115 There is, however, no lion painted on the page and thematically speaking, this epigram would have a much clearer and more obvious link to other biblical verses like Apoc. 5,5. ${ }^{116}$ If

111 Noticed by Emanuele Castelli. See the description by Sergey Kim in the ePTB/Pinakes database (Diktyon number 35991; cf. Gregory Aland number 1353), in the frame of the ERC project ParaTexBib.

112 See Andrist 2016a, 77 (Diktyon number 13159; cf. Gregory Aland number 556).

113 Besides, the relation paratext-protext can also be indirect. For example, if a paratext is a correction to the prologue of the Gospel of Matthew, it is the direct paratext to the prologue and-if one would care to think of it that way-an indirect paratext to Matthew. The prologue is then the direct protext of the correction and also the direct paratext to the Gospel of Matthew, which in turn is both the direct protext of the prologue and the indirect protext of the correction.

114 Diktyon number 8902; cf. Gregory Aland number 1. See also Brown 2016, 126 and Andrist 2016c, 87-95.

115 Nelson 1980, 25; type 1834 in the Database of Byzantine Book Epigrams.

116 At a stretch, one could argue that the "model of strength and courage" refers to the smaller painting of the Resurrection above the 
one sees this epigram simply as an independent piece of content with no obvious link to the material around it, one can say it is just a piece of (post-production) side-content. ${ }^{117}$ However, given the thematic link with the main core contents of the book (i.e. the four gospels), it makes more sense to consider the whole tetraevangelium as the protext of this epigram, which is not linked to any specific passage. Seen from this angle, the epigram resembles the prayers mentioned above and would be a paratext to the sacred book. In sum, the position of a text on a page does not automatically determine its paratextual nature. ${ }^{118}$

\subsection{The dynamics and perception of paratexts}

We would now like to draw particular attention to the fact that, for a large part, paratextuality depends on the historical situation and perspective of the reader. As we noted above, some parts of texts (like the prologue of Luke) might be considered to be a paratext by text historians. They would find themselves in disagreement, however, with book historians, who see it as a full part of the witness.

Inversely, titles-which were often added to texts in a somewhat arbitrary manner until tradition moulded their form into a relative degree of fixity-are clearly paratexts for book historians but might not necessarily be seen as such by producers. From their point of view, those titles, and probably also the prologues and the chapter divisions could have been considered a full part of the related "text-as-witness." For users of these books, such pieces of content probably had a sort of double function; as paratexts that helped them navigate and gave them better access to the text in various ways but also as intrinsic elements of their Bible.

Let us go back to the example of exegetical chains. As mentioned, these can be seen as either as a single long

portrait or to proclaiming the Incarnation in Ioh. 1. But, in the sentence, they refer to the word "lion," whose presence here is difficult to connect directly and internally with other elements of content in this book opening.

117 The ambiguous nature of this paratext calls to mind the similar situation we encountered earlier in Tetraeuangelium Bodmer 25.

118 In order to complete our overview of possible pieces of content in manuscripts, let us mention another category of contents, which are neither paratexts nor core-contents: the content on reused material, like the scriptura inferior of palimpsests or cut-out folios used as fly-leaves. In both cases, one will probably find situations where the scribe or the binder did choose specific reused material containing a thematic link with the content of the book he was working on, but the chances are very slim. Let us simply call these "reused material contents." paratext or as a part of a single "text-as-witness" containing both the Bible and the commentaries. In a related area, one finds illustrated versions of the book of Job in framed chain codices. Again, one can argue that depending on the reader's perspective, these books can be analysed both as biblical core texts "paratextualised" by glosses and images and as a single piece of content consisting of biblical, exegetical and graphic elements. Possibly, this is what happened at a certain point in the tradition: the producers and readers of these books no longer distinguished between the core content and their paratexts but viewed them rather as one single articulated piece of content. In any case, a wide range of analytical approaches enriches the discourse and leads to a more nuanced understanding of paratexts and their dynamics. If this is the case, one is tempted to extend the concept to New Testament books, and take the fairly frequent tetraevangelia containing four identically sequenced sets of Capitula-Portrait-Biblical text together as a single witness to one larger opus, created not by a single person but by a long tradition.

Gerard Genette warned us: "La paratextualité, on le voit, est surtout une mine de questions sans réponses." 119

\section{Perspective}

These theoretical considerations allow us to suggest the following working definition for the notion of paratext when used in the realm of manuscripts: "a piece of content whose presence in the manuscript-book is thematically dependent on one or several other pieces of content in the same book, or the book itself."

The study of paratexts in Greek New Testament manuscripts allows us to further distinguish between various types of contents and types of paratexts and to situate these with greater accuracy within the timeline of a book's production; in other words, whether they were added before or after the pivotal moment of the book project's completion.

Our method clearly distinguishes, as many authors implicitly do, between a) a paratext, according to the above repeated definition, $b$ ) the core-contents and side-contents which are not paratexts, $c$ ) the other aspects of the manuscript book which are outside the realm of its content per nature such as the ruling, quire signatures, layout, size of the characters etc., and d) the paratextual valence that some of these aspects may or may not have. It thus clarifies the terminology and as such, has the potential to facilitate

119 Genette 1982, 11 = 1997a, 4: “... a treasure trove of questions without answers.” 
discussions both within the field of manuscript studies and beyond it. It also strives to systematically cover all the possible types of contents in a manuscript book (see the summary table below).

As a result, from a book historical perspective, this analysis also gives full consideration to the book project that the paratexts were a part of when they were produced. Thus it supplements the historical study of these books with what can be learned from the nature and structure of their underlying projects, as far as their related contents are concerned. It is however not designed to limit or exclude the possibility (or indeed the existence) of different approaches to paratextuality in other fields of research.

Our discussion has had as its focus the study of paratexts as seen from a diachronic perspective rather than synchronous one. There are other, equally important aspects of paratextuality that fall beyond the scope of this paper but which certainly merit further study in the future. These include, for example, the various types of dependent relations between paratexts and protexts which, in turn, lead us to broader questions about the diverse functions and roles of paratexts.

As far as we can tell, the applicability of the definition as well as the above-mentioned limited scope of the article do not depend of any specific features of Greek or biblical manuscripts. It remains to be seen, of course, as part of a broader cooperative effort, how well these definitions and categories apply to other types of manuscripts and how much they will have to be adjusted or completed in order to comply with a more global theory of paratextuality in manuscript studies.

There are, nervertheless, good reasons to believe that a global theory of paratextuality in manuscript books is possible: the copying of a text always points to a person (or several people) making the decision to set it down in writing: taking writing materials (leather, papyrus, parchment, etc.) and ink (or something like it) in order to produce a more-or-less faithful text from a model or to "materialize" it for the first time or to paint a picture. Similarly, the act of producing a manuscript book (a scroll, a codex or another type) always points to people deciding to make it (including its content): taking some (already filled or still empty) pieces of writing material, assembling them, adding written content (if called for), and making the resulting object (including its content) available for circulation and use. A comparison of the resulting books from various cultural areas and/or various types of content should allow for the development of an appropriate, coherent and broadly accepted array of analytical tools and a set of concepts and expressions to describe, understand and classify all the related and implied aspects of paratextuality. This tentative analysis
Types of content in Greek New Testament manuscripts

A. Book producers' contents

1. Producers' core-contents

a. main core-contents

b. secondary core-contents

2. Producers'paratexts

a. traditional paratexts (mandatory, optional)

b. non-traditional paratexts

c. manuscript producers' paratexts

3. Producers' side-contents

4. Content on re-used material

B. Post-production contents

5. Post-production paratexts

a. reader's paratexts

b. book paratexts (sacred book paratext)

6. Post-production side-contents

C. Re-made book contents $=$ Book producers' contents (re-used core-contents; re-used paratexts...)

Figure 1: Summary table of the types of content in Greek New Testament manuscripts

of paratexts in Greek New Testament manuscripts from a diachronic perspective should be understood as a step in that direction.

\section{Bibliography}

P. S. Alexander/A. Lange/R. J. Pillinger (eds.), In the Second Degree : Paratextual Literature in Ancient Near Eastern and Ancient Mediterranean Culture and Its Reflections in Medieval Literature, Leiden 2010.

P. Andrist, Particularités de la couture en deux blocs du Genavensis grec 19, in B. Atsalos/N. Tsironi (eds.), Actes du VIe Colloque International de Paléographie Grecque (Drama, 21-27 septembre 2003), I-III (Biblioamphiastîs-Parartîma 1), Athína 2008, 427-43 + 1137-45 (plates).

-, The Physiognomy of Greek contra ludaeos Manuscript Books in the Byzantine Era. A Preliminary Survey, in R. Bonfil et al. (eds.), Jews in Byzantium. Dialectics of Minority and Majority Cultures (Jerusalem Studies in Religion and Culture 14), Leiden 2012, 549-85.

-, Syntactical Description of Manuscripts and The Physical Description, in A. Bausi et al. (eds.), Comparative Oriental Manuscript Studies. An Introduction, Hamburg 2015, 511-20, 521-30. Available at http://www1.uni-hamburg.de/COMST/ handbookonline.html.

-, Manuscrits grecs de la Fondation Martin Bodmer. Étude et catalogue scientifique (Catalogues Bodmer 8), Bâle 2016. (Andrist 2016a)

-, Structure and History of the Biblical Manuscripts used by Erasmus for his 1516 Edition, in M. Wallraff/S. Seidel Menchi/K. von Greyerz (eds.), Basel 1516. Erasmus' Edition of the New 
Testament (Spätmittelalter, Humanismus, Reformation 91), Tübingen 2016, 81-124. (Andrist 2016b)

-, Les codex grecs 'adversus ludaeos' conservés à la Bibliothèque Vaticane (s. XI-XVI). Essai méthodologique pour une étude des livres manuscrits thématiques (Studi e testi 502), Città del Vaticano 2016. (Andrist 2016c)

P. Andrist/P. Canart/M. Maniaci, La syntaxe du codex. Essai de codicologie structurale (Bibliologia 34), Turnhout 2013.

P. Andrist/M. Wallraff, ParaTexBib: an ERC Project Dedicated to Paratexts in Greek Manuscripts of the Bible, in COMST Bulletin 2, (2016), 63-68.

S. H. Aufrère/P. S. Alexander/Z. Pleše (eds.), On the Fringe of Commentary: Metatextuality in Ancient Near Eastern and Ancient Mediterranean Cultures (Orientalia Lovaniensia Analecta 232), Leuven 2014.

A. Biancastella/M. Santoro/M. G. Tavoni, Sulle tracce del paratesto, Bologna 2004.

G. J. Brooke, Hypertextuality and The "Parabiblical" Dead Sea Scrolls, in P. S. Alexander/A. Lange/R. J. Pillinger (eds.), In the Second Degree: Paratextual Literature in Ancient Near Eastern and Ancient Mediterranean Culture and Its Reflections in Medieval Literature, Leiden 2010, 43-64.

-, Physicality, Paratextuality and Pesher Habakkuk, in S. H. Aufrère/P. S. Alexander/Z. Pleše (eds.), On the Fringe of Commentary : Metatextuality in Ancient Near Eastern and Ancient Mediterranean Cultures (Orientalia Lovaniensia Analecta 232), Leuven 2014, 175-93.

A. J. Brown, The Manuscript Sources and Textual Character of Erasmus' 1516 Greek New Testament, in M. Wallraff/S. Seidel Menchi/K. von Greyerz (eds.), Basel 1516. Erasmus' Edition of the New Testament (Spätmittelalter, Humanismus, Reformation 91), Tübingen 2016, 125-44.

G. Castiglioni, La Chimèrea Officina: paratesto e poetica nelle edizioni di un torchio tipografico, in M. Santoro/M. G. Tavoni (eds.), I dintorni del testo. Approcci alle periferie del libro. Atti del convegno internazionale: Roma, 15-17 novembre 2004, Bologna, 18-19 novembre 2004 (Biblioteca di Paratesto 1), Roma 2005, 2: 579-585.

G. Ciotti/Lin Hang (ed.), Tracing Manuscripts in Time and Space through Paratexts (Studies in Manuscript Cultures 7), Hamburg 2016.

M. Curschmann, Anselm von Canterbury im Frauenkloster. Text, Bild, Paratext und Musik in einer Handschrift der 'Orationes sive meditationes' (Admont 289), in Wolfram-Studien 22 (2012), 79-130.

M. Cursi, La scrittura e i libri di Giovanni Boccaccio (Scritture e libri del medioevo 13), Roma 2013.

G. Dorival, Des commentaires de l'Écriture aux chaînes, in C. Mondesert (ed.), Le monde grec ancien et la Bible, Paris 1984, 362-86.

-, La postérité littéraire des chaînes exégétiques grecques, in Revue des études grecques 43 (1985), 209-26.

-, Les chaînes exégétiques grecques sur les Psaumes : contribution à l'étude d'une forme littéraire (Spicilegium sacrum Lovaniense, Études et documents 43-46), Leuven 1986-1995.

-, The Bible, Commentaries, Scholia, and Other Literary Forms, in S. H. Aufrère/P. S. Alexander/Z. Pleše (eds.), On the Fringe of Commentary : Metatextuality in Ancient Near Eastern and Ancient Mediterranean Cultures (Orientalia Lovaniensia Analecta 232), Leuven 2014, 163-74.
R. Dupont-Roc, Le texte du Nouveau Testament et son histoire, in D. Marguerat (ed.), Introduction au Nouveau Testament (Le monde de la Bible 41), $4^{\text {th }}$ edition, Genève 2008, 509-30.

B. D. Ehrman/M. W. Holmes (eds.), The Text of the New Testament in Contemporary Research (New Testament Tools, Studies and Documents 42), $2^{\text {nd }}$ edition, Leiden 2014.

J.-C. Fredouille et al. (eds.), Titres et articulations du texte dans les cuvres antiques. Actes du Colloque international de Chantilly 13-15 décembre 1994 (Collection des études augustiniennes. Série Antiquité 152), Paris 1997.

G. Genette, Introduction à l'architexte, Paris 1979.

-, Palimpsestes. La littérature au second degré, Paris 1982.

-, Seuils, Paris 1987.

-, Introduction to the Paratext, in New Literary History 22 (1991), 261-72.

-, The Architext: an Introduction (A Quantum Book), trans. by J. E. Lewin, Berkeley (Ca.) 1992.

-, Palimpsests, Literature in the Second Degree, trans. by C. Newman/C. Doubinsky, Lincoln (Neb.) 1997. (Genette 1997a)

-, Paratexts: Thresholds of Interpretation, Cambridge 1997. (Genette 1997b)

A. Hollander/U. Schmid/W. Smelik (eds.), Paratext and Megatext as Channels of Jewish and Christian Traditions. The Textual Markers of Contextualization (Jewish and Christian Perspectives), Leiden 2003.

L. Jansen (ed.), The Roman Paratext. Frame, Texts, Readers, Cambridge 2014.

A. Lange, In the Second Degree: Ancient Jewish Paratextual Literature in the Context of Graeco-Roman and Ancient Near Eastern Literature, in P. S. Alexander/A. Lange/R. J. Pillinger (eds.), In the Second Degree : Paratextual Literature in Ancient Near Eastern and Ancient Mediterranean Culture and Its Reflections in Medieval Literature, Leiden 2010, 3-40.

-, From Paratext to Commentary, in A. D. Roitman/L. H. Schiffman/ S. Tzoref (eds.), The Dead Sea Scrolls and Contemporary Culture: Proceedings of the International Conference Held at the Israel Museum, Jerusalem (July 6-8, 2008) (Studies on the Texts of the Desert of Judah 93), Leiden 2011, 195-216.

M. Maniaci, Il codice greco 'non unitario'. Tipologie e terminologia, in E. Crisci/O. Pecere (eds.), Il codice miscellaneo. Tipologie e funzioni. Atti del convegno internazionale (Cassino, 14-17 maggio 2003), Cassino 2004 (=Segno e Testo 2 [2004]), 75-107.

-, Problemi di mise en page dei manoscritti con commento 'a cornice'. L'esempio di alcuni testimoni dell'lliade, in Segno e testo 4 (2006), 211-98.

M. Maniaci/D. Muzerelle/E. Ornato, Une bible ... mais encore? Le portrait des manuscrits bibliques dans la catalographie moderne, in R. Schlusemann/J. M. M. Hermans/M. Hoogvliet (eds.), Sources for the History of Medieval Books and Libraries (Boekhistorische Reeks 2), Groningen 1999, 291-309.

G. Montecchi, La disposizione del testo nel libro antico, in M. Santoro/M. G. Tavoni (eds.), I dintorni del testo. Approcci alle periferie del libro. Atti del convegno internazionale : Roma, 15-17 novembre 2004, Bologna, 18-19 novembre 2004 (Biblioteca di Paratesto 1), Roma 2005, 1: 191-205.

R. S. Nelson, The Iconography of Preface and Miniature in the Byzantine Gospel Book (Monographs on Archaeology and the Fine Arts 36), New York 1980.

D. C. Parker, An Introduction to the New Testament Manuscripts and Their Texts, Cambridge 2008.

-, Codex Sinaiticus, London 2010. 
A. K. Petersen, Textual Fidelity, Elaboration, Supersession or Encroachment? Typological Reflections on the Phenomenon of Rewritten Scripture, in J. Zsengellér (ed.), Rewritten Bible after Fifty Years: Texts, Terms, or Techniques? A Last Dialogue with Geza Vermes (Supplements to the Journal for the Study of Judaism 166), Leiden 2014, 13-44.

M. Regoliosi, Il paratesto dei manoscritti, in Paratesto 3 (2006), 9-33.

P. Robinson, Towards a Theory of Digital Editions, in Variants 10 (2013), 105-31.

U. Rozzo, Il paratesto e l'informazione bibliografica in Paratesto 3 (2006), 211-31.

P. Sahle, Digitale Editionsformen. Zum Umgang mit der Überlieferung unter den Bedingungen des Medienwandels. Teil 3: Textbegriffe und Recodierung (Schriften des Instituts für Dokumentologie und Editorik 9), Norderstedt 2013.

M. Santoro/M. G. Tavoni (eds.), I dintorni del testo. Approcci alle periferie del libro. Atti del convegno internazionale : Roma, 15-17 novembre 2004, Bologna, 18-19 novembre 2004 (Biblioteca di Paratesto 1), Roma 2005.

E. Scherbenske, The Vulgate Primum Quaeritur, Codex Fuldensis and the Hermeneutical Role of Early Christian Introductory Materials, in A. Cameron et al. (eds.), Papers Presented at the Fifteenth International Conference on Patristic Studies Held in Oxford 2007 (Studia Patristica 44), Leuven 2010, 139-44.

-, Canonizing Paul: Ancient Editorial Practice and the Corpus Paulinum, Oxford 2013.

M. Scherner, „TEXT“. Untersuchungen zur Begriffsgeschichte, in Archiv für Begriffsgeschichte 39 (1996), 103-60.

M. Schwarz-Friesel/M. Consten, Einführung in die Textlinguistik, Darmstadt 2014.
D. Stökl Ben Ezra, Reading Ritual with Genette: Paratextual and Metatextual Aspects of the Bible in Ritual Performances, in S. H. Aufrère/P. S. Alexander/Z. Pleše (eds.), On the Fringe of Commentary: Metatextuality in Ancient Near Eastern and Ancient Mediterranean Cultures (Orientalia Lovaniensia Analecta 232), Leuven 2014, 195-217.

M. A. Terzoli (ed.), I margini del libro. Indagine teorica e storica sui testi di dedica. Atti del Convegno internazionale di studi, Basilea, 21-23 novembre 2002 (Miscellanea erudita. Nuova serie 67), Roma 2004.

E. Tov, Paratextual Elements in the Masoretic Manuscripts of the Bible Compared with the Qumran Evidence, in B. Kolbmann et al. (eds.), Antikes Judentum und Frühes Christentum, Festschrift für Hartmut Stegemann zum 65. Geburtstag (Beihefte zur Zeitschrift für die neutestamentliche Wissenschaft 97), Berlin/ New York 1999, 73-83.

-, Scribal Practices and Approaches Reflected in the Texts Found in the Judean Desert, Leiden 2004.

M. Wallraff/P. Andrist, Paratexts of the Bible: A New Research Project on Greek Textual Transmission, in Early Christianity 6 (2015), 237-43.

M. Wallraff, The Canon Tables of the Psalms. An Unknown Work of Eusebius of Caesarea, in Dumbarton Oaks Papers 67 (2013), 1-14.

-, Kodex und Kanon. Das Buch im frühen Christentum (Hans-Lietzmann-Vorlesungen 12), Berlin 2013.

-, Die Kanontafeln des Euseb von Kaisareia. Paratexte der griechischen Bibel I (Manuscripta Biblica), Berlin, forthcoming.

J. J. van Zundert, By Way of Conclusion: Truly Scholarly, Digital, and Innovative Editions?, in T. Andrews/C. Macé (eds.), Analysis of Ancient and Medieval Texts and Manuscripts: Digital Approaches (Lectio 1), Turnhout 2014, 335-46. 
